\title{
Collective emotions and the World Cup 2014: The relevance of theories and research on collective pride and shame
}

\author{
Gavin Brent Sullivan ${ }^{1}$
}

\begin{abstract}
Brazil's recent experiences in the semi-final of the 2014 World Cup show the potential for collective shame that is potentially, but rarely, realized as representative teams, fans and nations dream of international sporting successand positive international attention from mega-sporting events. Feelings of shock, deep disappointment and anger in Brazil are examined as manifestations of group-based and collective shame after the semi-final defeatfor the host nation's supporters and humiliationof the national team. I explored "bottom up" mechanisms and other means by which collective shamearguably occurred due to high expectations and national narratives built around footballing success. The analysis includes the complex social and relational means by which Brazil's representative team failed to "restore pride" by returning to previous minimal standards in the third-place playoff and the fortunatemanner further humiliation for Brazilians was avoided through the German team's subsequent victory over Argentina in the final. The brief collective emotion analysis is completed with an examination of lessons that might be learned from Germany's long process of transformation from collective shame after the Second World War to the eventual experience of a cosmopolitan national pride through football at the World Cup 2006 tournament and other subsequent international successes.
\end{abstract}

Keywords: collective shame; collective pride; group-based emotions; World Cup; mega-sporting events.

When nations bid for a mega-sporting event like a World Cup or Olympics, they usually describe the potential legacy that includes positive benefits of collective emotion, national identity and social cohesion. In contrast to tangible stadia and other infrastructure that are built for a tournament, the emotional and identity legacy for hosts of mega-sport events is often described as intangible (Burbank, Andranovich, \& Heying, 2012). Happiness is one of the intangible benefits examined by megasporting event researchers (Kesenne, 2012) which is evident when the hosts of a tournament are widely perceived as having organized a very good event and the home team performs well (Sullivan, 2009). However, the term "intangible" seems inappropriate for Brazilians watching the loss of their team to Germany in the 2014 semi-final. This is because the raw emotions were undeniable, spontaneous, difficult to suppress, deeply felt and could easily be seen on the faces (e.g., tears), bodies (e.g., slumped) and in the interactions of Brazilian supporters (e.g., withdrawing from or seeking to comfort each other). In short they were very "real" rather than "immaterial".

Such feelings contribute to and are derived from widely shared emotions of group or collective shame in relation to the same event that can arguably have an objective existence as an "emotional climate" (de Rivera, 1992; Pettigrove \& Parsons, 2012). This latter feature of the recent shared emotions in Brazil - meaning emotions expressed with other people as well as coordinated with others so that they are described as feeling the same to most group members - is a vivid and very recent example of the relatively underexplored topic of collective emotion (von Scheve \& Salmela, 2014). Although features of the individual impact of events on fans, supporters and group members have been studied in terms of individual

\footnotetext{
${ }^{1}$ Reader in Identity and Resilience in Communities and Organisations Centre for Psychology, Behaviour and Achievement at Coventry University - Coventry, United Kingdom. E-mail: gavin.sullivan@coventry.ac.uk.
} 
experiences of "reflected glory" (e.g., when your team wins; Cialdini et. al., 1976) and "cutting off-reflected failure" (when your team loses; Snyder, Lassegard, \& Ford, 1986), theories and studies of group-based emotions - feelings or affects that are felt on behalf of a group that one is a member of - and collective emotions - widely shared and socially coordinated occurrences of positive or negative emotion within a group towards a shared object of attention - can be used to understand why people come to feel emotions like these and how they can be shared by millions of people simultaneously.

In this paper, my aim is to clarify the connections between individual group-based and collective forms of emotions: particularly, dynamic representations of collective shame and collective pride which show their strategic, flexible and sometimes unpredictable effects on individuals, groups and nations. The goal is not only to focus on negative group-based and collective disappointment and shame but also to explore positive group-based and collective celebrations and pride. Although the examples are derived from Brazil and Germany, respectively, an important general assumption here is that all emotions demonstrate flexible and strategic features as individual and groups negotiate complex social and relational contexts (Burkitt, 2014). For example, Brazilians who identify strongly with football as a barometer of the nation's wellbeing and its status among nations are still coping with their national team's capitulation to Germany. Germans, in contrast, can enjoy the success that has been a long time in the making as the nation has emerged from the collective shame of its Nazi past, the Holocaust, Second World War and reunification to now be able to celebrate national successes without feeling collective guilt or widespread concerns that this will reignite a domineering and aggressive nationalism.

In addressing these topics, the structure of this brief article is as follows. I will examine two instances of collective emotion that occurred towards the end of the tournament. In presenting and applying the latest theory and research on collective emotions (e.g., von Scheve \& Ismer, 2013), first I examine Brazil's collective shame at the outcome of the semi-final and I then explore factors leading to the contrasting positive emotions in Germany after the World Cup final (i.e., collective pride; Sullivan, 2014a, 2014b). An important feature of this analysis is that these contrasting collective emotions are not seen in isolation, but rather in dynamic relations that say much about the complex contexts of globalised cooperation and competition in which celebrations and disappointments both reflect and produce social and relational shifts between nation states.

\section{Collective shame and the Brazilian team's semi-final World Cup defeat}

As outlined in the introduction, hosting and participating in a mega-sport event is usually seen as ultimately worth the investment if an event leaves a positive legacy for a host nation. Obviously, it is usual for concerns prior to an event to be expressed about the cost and the potential for security issues, the effects of an influx of tourists and potential embarrassments (e.g., disruptions by protestors, organisational mistakes, etc.). The widespread anxiety that occurs before the start of a tournament arguably reflects an unacknowledged fear of collective shame; that is, anxiety about what could go wrong rather than what will be great. Generally, once a tournament is underway, the host's team are deemed to be competitive and there are no major problems with the tournament, early anxieties evaporate and enthusiasm for the event within the host nation spreads (sometimes even to include previously marginalized groups). In some cases, as in World Cup 
in Germany 2006, this culminates in collective pride and euphoria (Sullivan, 2009). In that case, intense positive emotions occurred despite a third-place finish in part because the German national team had exceeded expectations by playing in an uncharacteristically positive style, the event itself created a month-long carnival atmosphere and international feedback was positive.

But widespread aspirations to achieve a significant goal and experience group, collective or national pride potentially generate euphoria, solidarity and social cohesion or shame, disappointment, disbelief and social disintegration. From an international viewing perspective, the semi-final game between Brazil and Germany stands out in the history of mega-sport events principally because such a loss for a host is new territory. The nature of the Brazilian team's defeat by Germany, however, shows the rare counter to national pride: realization of the possibility of experiencing collective shame. There are few more stunning examples in recent memory of the ruthless exposure of the "risks" of a World Cup host nation's enthusiasm and desire to experience a national celebration that recent events in Brazil. The shock, disappointment and disbelief of Brazilian supporters were evident in international broadcasts of their reactions in the stadium. It is very likely that these images were imitated by and further affected the wider Brazilian viewing public (and potentially also stimulated schadenfreude among traditional football rivals). However, "bottom-up" collective emotion generating mechanisms of imitation of facial expressions (von Scheve \& Ismer, 2013) tell only part of the story here. Initial reactions to the realization that Brazil would not win altered further as the game progressed and there were further reactions to the increasing scoreline. Thus the collective emotions experienced were the product of interactions between people and in relation to the humiliating nature of the defeat. A relevant insight here from social theorists is that anger will begin to be expressed by some and will be directed towards pre-existing targets (e.g., the Brazilian President) and, potentially, the team. Scheff (2007) argues that this anger is not just the result of thwarted ambitions, but is a way in which feelings of humiliation and shame are "bypassed". One implication of such reactions is that aggression and violence can increase; a largely unreported outcome is also that defeats lead to increases in domestic violence (e.g., after a game among viewers at home; Laville, 2014). Of course, for the difficult-to-estimate number of citizens who were not interested in the tournament or who actively resisted any emotional investment in it, their experiences and perceptions are hidden from the dominant narrative of shame in the national and international press. An additional notable point is that shame can have a positive function; that is, widespread acknowledgement of collective shame may be productive in overcoming withdrawal and the individualising effects of the emotion (e.g., such as not feeling able to face other people and being temporarily unable to function in everyday life) by motivating a variety of forms of restorative activity.

The national narrative (or meta-narrative) of Brazilian shame is a good example of a top-down mechanism of collective emotion (von Scheve \& Ismer, 2013) which can shape the narratives of individuals and, at minimum, imply that particular emotional reactions are normative. Interestingly, the lack of shame on the part of any particular Brazilian citizen could be taken to indicate that they were not patriotic to begin with (or what is often called a "high identifier" in the literature on group-based emotions). Discussion of collective shame also helps to clarify the importance of shared collective aims which are experienced as shared concerns in what Tuomela (2013) has called "we-mode" - which is to think, feel and act as a group member (e.g., focusing on how "we" will win the World Cup) which contrasts 
with personal concerns in what can be a pro-social "I-mode" (e.g., my personal preference as an independent observer not to see Brazilians in distress). Therefore, a single-minded, widely shared focus on winning will increase the collective pain of defeat. Moreover, when expectations of success can only be satisfied by winning the event itself and the expense of hosting the event is unacceptable to many then the risk of negative collective emotions is multiplied further.

Another feature of Brazil's semi-final loss is important to examine in an analysis framed in terms of collective emotion. The loss was not just humiliating because another team inflicted the defeat on the Brazilian team and, by implication, Brazilian supporters; as odd as it sounds, it is also the Brazilian team's active rather than passive contribution to the historically bad result by failing to mount sufficient resistance that means it is appropriate to talk of collective humiliation and shame. When sporting events go wrong for the host nation they rarely occur in such an emphatic fashion that supporters feel that the team has done this to themselves and the nation (i.e., they are reasonably described as responsible for the outcome).

In such circumstances, stories about groups is that they are evoked and reworked to make sense of events (e.g., connections with previous traumas in collective memory like Brazil's 1950 World Cup loss at home to Uruguay are recalled). However, there are limits to the usefulness that this narrative meaning-making has for a group because further unpredictable contingencies can occur. For example, losing to Germany created the prospect of further unpredictable mixtures of collective shame, pride and anger that could have had further negative effects on the potentially fragile sense of national identity of Brazilians as they looked to the future in the immediate aftermath of the semi-final. National pride is built on multiple factors and sources that include a sense of belonging, identification with a range of ingroup cultural practices and values that are usually regarded as positive and widespread. In this respect, the collective pride of Brazilians is likely to be resilient because one football loss does not change a nation's economic and cultural circumstances. However, the progression of Argentina to the final raised the real and potentially intolerable prospect of Brazil's bitter rivals winning the host's tournament. The strategic switch of Brazilians to support Germany not only indicated how admiration for a victorious rival can occur (if there is sufficient distance in terms of intergroup relations) but also how a German victory over Argentina in the final could help to avoid a further humiliation.

\section{Restoration of collective pride and the example of German success}

Of course, the process of a recovery of collective pride is primarily about what a group does for itself rather than the favours that are provided by others. For Brazilian team and the nation, it seemed that such restoration could begin with a reasonable performance - what could be called a return to maintaining previously "proud" minimal standards by the national team - along with recognition that there are many other reasons why Brazilians can feel successful and powerful. However, the result of the semi-final game between Brazil and Holland did not represent the desired restoration of national pride but it is here that some lessons might be learned from Germany's national team and, indeed, the history of the German nation. In the shifting matrix of globalized national identities, it is an unexpected outcome of the World Cup 2014 that the affective relations between Germany and Brazil are now closer than before the tournament. The closeness that Brazilians feel towards Germany 
for sparing them the shame of an Argentinian World Cup victory on home soil may also encourage reflection on how Germany has used football to transform its international image and rebrand its nation (arguably something that Brazil can still achieve with the 2016 Olympics). This might lead Brazil to examine relevant aspects of the German national team's long road to success and the first victory for Germany as a reunified nation.

In a similar manner to Brazil, the German national team is a personification of the nation that now reflects a multicultural and cosmopolitan society as well as a wider pattern of increasing success, status and positioning in international relations. But the collective pride that can be felt through supporting the national team and celebrating their accomplishments signifies profound changes in German collective shame about the period of Nazi rule and the Second World War (Sullivan, 2014c). The German win in 2014 hopefully continues a trend in which the celebrations of significant international football victories are largely positive and reflect cosmopolitan values rather than the collective hubris and arrogance associated with right-wing extremism. The determination to avoid past mistakes and collective hubris is evident in the interest that Germans have in reading about how other countries interpret German success (i.e., to conform with an image of a successful German nation considered from the perspective of others). By implication, contemporary sources of the complex and ambivalent national narratives of Brazil (Kühn, 2014) need to be addressed by engaging with outsider perspectives and through social and political action that leads to genuine improvements in the quality of life of all Brazilians. For Brazil, collective action to address societal inequality and social infrastructure will arguably provide the basis upon with performances in the Olympics as a host and competitor will build upon rather than be a supplement for broader achievements.

\section{References}

Burbank, M. J., Andranovich, G., \& Heying, C. H. (2012). Mega Events and Local Politics. In W. Maenning \& A. Zimbalist (Eds.). International Handbook on the Economics of Megasporting Events (pp. 162-176). Northampton, MA: Edward Elgar.

Burkitt, I. (2014). Emotions and Social Relations. London: Sage.

Cialdini, R. B., Borden, R. J., Thorne, R. J., Walker, M. R., Freeman, S., \& Sloan, L. R. (1976). Basking in reflected glory: Three (football) field studies. Journal of Personality and Social Psychology, 34, 366-375.

de Rivera, J. (1992). Emotional climate: Social structure and emotional dynamics. In K. T. Strongman (Ed.). International Review of Studies on Emotion (Vol. 2, pp. 197-218). Wiley: Chichester.

Kesenne, S. (2012).The Economic Impact, Costs and Benefits of the FIFA World Cup and the Olympic Games: Who Wins, Who Loses? In W. Maenning \& A. Zimbalist (Eds.). International Handbook on the Economics of Megasporting Events (pp. 270-278). Northampton, MA: Edward Elgar.

Kühn, T. (2014). Constructions of belongingness in late modernity: national pride in Brazil form a social inequality research perspective. In G. Sullivan (Ed.). Understanding Collective Pride and Group Identity: New directions in emotion theory, research and practice (pp. 161-172). London: Routledge.

Laville, S. (2014, June 8). Police fear rise in domestic violence during World Cup. Retrieved from http://www.theguardian.com/society/2014/jun/08/police-fear-rise-domestic-violence-world-cup.

Pettigrove, G., \& Parsons, N. (2012). Shame: A case study of collective emotion. Social Theory and Practice, 38, 1-27. 
Scheff, T. (2007). Runaway nationalism: alienation, shame and anger. In J. L. Tracy, R. W. Robbins, \& J. P. Tangeny (Eds.). The Self-Conscious Emotions: Theory and Research (pp. 426-439). New York: Guilford Press.

Snyder, C. R., Lassegard, M., \& Ford, C. E. (1986). Distancing after group success and failure: Basking in reflected glory and cutting off reflected failure. Journal of Personality and Social Psychology, 51, 382-388.

Sullivan, G. B. (2009). Germany during the 2006 World Cup: The role of television in creating a national narrative of pride and "party patriotism". In E. Castelló, A. Dhoest \& H. O'Donnell (Eds.). The Nation on Screen, Discourses of the National in Global Television (pp. 235-252). Cambridge: Cambridge Scholars Press.

Sullivan, G.B. (Ed.) (2014a). Understanding Collective Pride and Group Identity: New directions in emotion theory, research and practice. London: Routledge.

Sullivan, G. B. (2014b). Collective pride, happiness and celebratory emotions: Aggregative, network and cultural models. In C. von Scheve \& M. Salmela (Eds.). Collective Emotions: Perspectives from Psychology, Philosophy, and Sociology (pp. 266-280). Oxford: Oxford University Press.

Sullivan, G.B. (Ed.) (2014c). Collective emotions, German national pride and the 2006 World Cup. In G. Sullivan (Ed.). Understanding Collective Pride and Group Identity: New directions in emotion theory, research and practice (124-136). London: Routledge.

Tuomela, R. (2013). Social Ontology: Collective Intentionality and Group Agents. Oxford: Oxford University Press.

von Scheve, C., \& Ismer, S. (2013). Towards a theory of collective emotions. Emotion Review, 5, 406-413.

von Scheve, C., \& Salmela, M. (Eds.). (2014). Collective Emotions: Perspectives from Psychology, Philosophy, and Sociology. Oxford: Oxford University Press. 